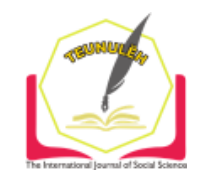

Jurnal Ilmiah Teunuleh

The International Journal of Social Sciences

Vol. 1, Issue. 2, Dec 2020

E-ISSN: 2746-4393

\title{
STUDY OF ILLOCUTIONARY SPEECH IN TRADITIONAL MARKETS IN PRAGMATIC PERSPECTIVE
}

\author{
M. Riyanton ${ }^{1}$ \\ Mustasyfa Thabib Kariadi ${ }^{2}$ \\ Umi Ana Setiani ${ }^{3}$ \\ ${ }^{12}$ Universitas Jenderal Soedirman, ${ }^{3}$ Universitas Muhammadiyah Purwokerto \\ ${ }^{1}$ m.riyanton@unsoed.ac.id, ${ }^{2}$ mtkariadi_pbi@unsoed.ac.id, ${ }^{3}$ anaumisetiani@gmail.com
}

\begin{abstract}
The interaction conducted by traders with buyers in Kejajar Wonosobo Market intends to reach a final agreement in transaction activities. In the final agreement there is an interesting thing that needs to be observed, namely the use of certain words that have the influence of the seller on the buyer. The power of influence is a speech that can be understood by speakers and speech partners. The power of influence is known as the act of speech ilokusi. In this article the author aims to describe the type and function of ilokusi speech and relevance to Indonesian language learning in high school. Based on the results of data analysis found 41 speech data included in the type and function of ilokusi speech actions carried out by sellers with buyers in Wonosobo Kejajar Market. The data included 7 data on expressive speech types, 17 data on the type of corrective speech directive, 11 data on the type of corrective speech, and 6 data on the type of commissionive speech, while the type of declarative ilokusi speech was not found. In addition, the ilokusi speech function was found to consist of 17 competitive function data, 13 convivial function data, 11 collaborative function data, while for conflictive ilokusi speech function was not found. Furthermore, the results of this study were integrated into Indonesian language learning in negotiation text material in high school grade $X$, in KD 3.11: Analyzing the content, structure (orientation, submission, offer, approval, closing) and language of the negotiating text.
\end{abstract}

Keywords: Speech, Illocution, Traditional Markets.

\section{A. Introduction}

Language is a communication device that is arranged and arranged in the form of linguistic units such as words, clauses, and sentences expressed in writing or verbally 
through a speech in the conduct of various human activities. Language can also be interpreted as a place of reflection of culture, through human language can adjust to the people both customs, behavior, karma system of the community, and blend in all forms of society (Riyanton: 2020).

Speech can be used by anyone, anytime, and anywhere, as is the case in various crowded places. One of the crowded places that are often encountered by speech acts is the market. Researchers chose Wonosobo Kejajar Market as a place to collect data in the research. Wonosobo Kejajar Market is a place that is often visited by residents located in the area around Kejajar District, Wonosobo Regency. This market is strategic because it is close to community settlements. Kejajar Market is one of several traditional markets located in Wonosobo Regency. Complete primary needs are found in Wonosobo Kejajar Market at a cheaper price, so many local people go to this market to look for their daily needs. To get something needed in the market, of course buyers around Kejajar must interact with the seller. Interaksi done by using a speech in the form of language. Important analysis in language marriage is the intention of speakers to speech partners that are adjusted to the situation, time, events, process, state of the speech partner (Prayitno, 2009:133)

Every interaction carried out by traders with buyers in Wonosobo Kejajar Market, there is a certain purpose in it, namely to reach a final agreement in transaction activities. The interaction in Wonosobo Market, especially between sellers and buyers, is interesting to research. One of the interesting things in this market is the interaction of traders with their buyers. Interaction between sellers and buyers from within the market is using a language astuturan, besides the type of speech used is caused by the existence of various forms soldin thismarket both goods and services, so that it can make it easier for researchers to understand correctly a speech that is taught. The occurrence of commercial activities carried out by traders with buyers in Wonosobo Kejajar Market is inseparable from the existence of a speech. The existence of trade interaction activities in Wonosobo Kejajar Market using certain words that have influence for both, so that it makes researchers encouraged to try to research and focusresearch onthe illocution speech used in Wonosobo Kejajar Market. The illocution speech used in Wonosobo Kejajar Market has a certain appeal that can reach an expected agreement. The study in this study intends to find out exactly how the use of illocution speech action contained in Wonosobo Kejajar Market. 
The analysis conducted in Wonosobo Kejajar Market on illocution speech can be used in the implementation of Indonesian language learning in the revised 2013 curriculum 2017 which is adjusted based on the Basic Competency of the second semester high school level, namely in the class $X$ negotiation text material. The Basic Competency is KD 3.11 analyzing the content, structure (orientation, submission, offer, approval, and closing) and language of negosisaitext, d engan thus the research entitled "Illocution Speech in Seller and Buyer Interaction in Wonosobo Market and Relevance to Indonesian Language Learning in High School" is important.

Thisresearch can not be separated from the results of previous studies that were used as a reference. Previous relevant researches are Ediwarman research (2019), Guntari research (2019), and Herliana research (2019). The first research was conducted by Ediwarman (2019). Ediwarman's research focuses the study on the function and category of illocution speech acts contained in the novel Sinking van Der Wijck by Buya Hamka. Ediwarman's research similarity with this research is analyzing the actions of illocution speech that leads to its function and categorical. The difference is that Ediwarman's research uses Buya Hamka's novel entitled Sinking van Der Wijck as a source of research data collection which then the dialogues in the novel are classified related to the function and categorical of the illocutionnya speech, while the author takes a direct speech in Wonosobo Kejajar Market as a source of data retrieval.

Then Guntari (2019) conducted research that focuses on the form of speech directives and types of speech acts used by guest stars in the Indonesia Lawyers Club TV One. Similarity of Guntari research and this research both examined the act of speech, namely the act of illocution speech, but the difference is in the focus of research and data sources obtained, if Guntari research refers more to the analysis of the type of speech illocution directive, this research focuses on the type of speech illocution as a whole and its function, as for the source of data obtained from guntari research comes from speech actions carried out by guest stars at the Indonesia Lawyers Club TV OneEvent, while this research comes from direct speech by sellers and buyers in Wonosobo Kejajar Market..

Further research was conducted by Herliana (2019). Herlina's research examined the form of Indonesian and Mandarin illocution speech actions carried out by teachers during the learning process in the D3 study program of Mandarin Unsoed Purwokerto. Penelitian Herliana has similarities with this research that is the content of studying about the act of speech illocution. The differencelies in data analysis method using agih method, while researchers in analyzing data using padan method. 


\section{B. Theoretical Studies}

\section{Pragmatic}

Leech (1983:13) Pragmatics as part of the language studies language in its use that integrates with grammar, among which are phonology, morphology, semantics and syntax. Pragmatics is an offshoot of language science that examines the user's use of that language.

\section{Speech Context}

Leech (1993) revealed that context as an aspect related to the environment, both the physical and socialenvironment of a speech and the background shared by speakers and speech. Context understanding refers to an environmental situation to clarify a point so that it can be understood by the speech participants involved in the conversation.

\section{Speech}

Putrayasa (2014:85) states that speech is an individual state determined by the language proficiency possessed by the speaker psychologically in the face of certain situations. Speech is an act of communication carried out by a speaker based on his language skills in certain environmental situations and with special purposes.

\section{Follow Illocution Speech}

A person does not only produce a good speech without a purpose. Yule (2006:84) in his book says that a person produces a speech with the existence of functions in the mind that he calls the second dimension of illocution action. The act of illocution speech is the act of speech produced by the existence of a function in the human mind that can influence the speech partner to act to do something expected by the speaker.

\section{Types of Illocution Speech}

According to Searle (in Leech, 1993:163-165) illocution acts are grouped into five types, namely Asertif, Directive, Commissionive, Expressive, and Declarative which can be explained as follows:

a. Assertives, a form ofspeech that binds the speaker to the expression of the truth of the proposition. Like stating, proposing, bragging, complaining, expressing opinions, reporting.

b. Directives, a form of speech intended to give an effect in the form of actions performed by speakers. For example ordering, ordering, begging, demanding, and advising. 
c. Commissions (Commissives), a form of speech that is tied to future actions. For example promising, offering, berkaul.

d. Expressives (Expressives), a form of speech that serves to express or show the psychological attitude of speakers towards a situation. Such as thanking, congratulating, apologizing, praising, criticizing or criticizing, and expressing condolences.

e. Declaration (Declaration), a form of speech with conformity between the content of the proposition and reality. For example, resigning, baptize, fire, name, sentence, excommunicate or discard, and appoint (employees). It is based on function.

\section{Illocution Speech Act Function}

Searle (in Leech, 1993:162) argues that the function of illocution in accordance with the relationship of function and social purpose in the form of maintenance of polite and respectable behavior can be classified into four kinds. The functions are competitive, cooperating, fun, and contradictory functions.

a. CompetitiveFunction

Competitive function is speech that does not have manners so manners are involved in this, for example asking for money loans in a forceful tone.. The purpose of illocution along with the existence of social goals. In this function of illocution, manners have negative traits that aim to reduce disharmony, such as governing, demanding, asking, and begging.

b. Fun Function(Convivial)

Fun function is speech that has karma system.. The purpose of this illocution is in harmony with social goals. Manners in this function have a more positive form and intend to look for opportunities to be friendly, such as inviting or inviting, offering, greeting, congratulating, and saying thank you.

c. CollaborativeFunction

The function of working together is a function that does not include manners in it, it is because in this function manners are irrelevant or unrelated. Not caring about social goals is the purpose of the illocutionnya, for example, such as reporting, announcing, stating, and teaching. 


\section{d. Conflictive Functions}

Basically this function intends to cause the onset of anger therefore this function has no element of manners in it. Contrary to social purposes is the purpose of this illocution, for example accusing, cussing, threatening, and scolding.

\section{Research Method}

According to Bogdan and Tylor (in Ismawati 2012:7) explained that qualitative research as a research step that brings up descriptive data in the form of written and oral words from the behavior of a person that can be observed, in addition to the whole approach is directed at the individual and his background. This study used data sources derived from the direct speech of sellers and buyers in Wonosobo Kejajar Market by recording the sound either involved as buyers or not using mobile phones without telling participants, it was done so that the data obtained naturally without engineering, then the data produced from this research is processed using words or sentences without any calculation of numbers.

The data in this study is in the form of speeches that are suspected to contain the type and function of illocution tuitur action.. The data source of the research comes from a direct speech conducted by the seller with buyers in Wonosobo Kejajar Market from the results of unstructured observations and voice recordings using mobile phones. In this study, researchers chose simak method as the data collection method used. Called the method of "simak" or penyimakan: done by listening, namely listening to the use of language (Sudaryanto, 2015:203). There are two techniques in the simak method, namely basic techniques and advanced techniques.. Basic techniques of the method of listening in the form of tapping techniques, meaning that efforts in obtaining data are carried out by researchers by tapping the use of language or conversations between sellers and buyers, while the follow-up techniques are the technique of listening to proficient libat, proficient libat-free techniques, recording techniques, and noterecording techniques.

The method used to analyze the data in this research is the padan method. Sudaryanto (2015:15) explained that the padan method is a method determined by a penenentu tool outside the language and not part of the language in question. Metode padan used in this research is a method of padan whose determining tool is language or referent language (what is talked about) or commonly referred to as referential method. 
The padan method is continued with two techniques, including basic techniques and advanced techniques. The basic technique used is the technique of determining element (PUP) that is the language itself in order to be found speech temasuk into the act of illocution speech, while the follow-up technique of comparative relationship technique (HBS) to equate speech data containing illocution speech action with existing theories so that the type of illocution speech action can be found, and distinguishing comparative techniques (HBB techniques) are used to distinguish functions from each other, and comparative connective techniques (HBB techniques).

a. Table

Table 1. Types of illocution speech

\begin{tabular}{|l|c|c|c|c|c|c|}
\hline $\begin{array}{l}\text { Types of } \\
\text { Illocution Speech }\end{array}$ & Expressive & Directive & Asertif & Commission & Declarative & Amount \\
\hline Data found & 7 & 17 & 11 & 6 & - & 41 \\
\hline
\end{tabular}

Table 2. Illocution Speech Act Function

\begin{tabular}{|l|c|c|c|c|c|}
\hline $\begin{array}{l}\text { Illocution Speech } \\
\text { Act Function }\end{array}$ & Competitive & Fun (convivval) & Collaborative & Conflictive & Amount \\
\hline Found Data & 17 & 13 & 11 & - & 41 \\
\hline
\end{tabular}

\section{Results and Discussion}

This section contains a description of the results of research and discussion. The results of the study in the form of speech data in the interaction of sellers and buyers who are suspected to contain illocution speech in Wonosobo Kejajar Market. The discussion in this research is explained descriptively qualitatively. The results of research and discussion include (1) Types of illocution speech actions in the interaction of sellers and buyers in Wonosobo Kejajar Market, (2) The function of illocution speech in the interaction of sellers and buyers in Wonosobo Kejajar Market, (3) Relevance of the results of illocution speech research in the interaction of sellers and buyers in Wonosobo Kejajar Market to Indonesian language learning in high school. Based on the statement above, the results of research on illocution speech in the interaction of sellers and buyers in Wonosobo Kejajar Market are as follows.

\section{Types and Functions of Local Speech}

a. Data (2)

Context: 
Conversations take place between chicken traders (P2) and buyers (P1), buyers intend to buy chicken as an ingredient to make meatballs, buyers ask for clean chicken meat for ingredients to make meatballs at a cheaper price.

P2: "Tigo gangsal nggeh monggo, biasane nek yaheten mpun telas" ("Thirty-five yes please, usually if this time is up")

P1: "Ya tigang kilo" ("Yes three kilos")

P2: "Damel bakso?" ("Make meatballs?)

P1: "Nggeh, seng resik. La kono mboten dipendet gulune? Milu timbang?" ("Yes, that's clean. He didn't take his neck? Weighed in?")

P2: "Mangken" ("Later")

P1: "Milu timbang?" ("Weighed?")

P2: "Ya enggeh lawong aleng ngenu mbokan mangken benten, benten regine" ("Yes it will be different times, different price")

P1: "Hahaha lucu" ("Hahaha funny")

P2: ("cut into chicken meat")

P1: "Gulune pendet aken niku" He said, "How will this be?"

P2: "Enggeh, pundut niki nopo niki pundut?" (Pointing to the part of the chicken to be taken)

("Yes, it was taken, was it taken?")

P1: "Nggeh resik. Belunge be wis ana sekilo yo!"

("Yes clean. There's already a kilo of bones!")

P2: "Enggeh, mulane niki kaleh kilo si, ya kurang, kaleh kilo seprapat." ("Yes that's why its two kilos right, less, two kilos a quarter")

P1: "Pinten dadose?" How much is it?"

P2: "Satus limo" "One hundred and fifty thousand"

P1: "Suwun" ("Thank you")

Data number (2) in the form of a "Thank you" speech delivered by the buyer to the seller of chicken meat as opposed to his speech. The speech "Thank you" contains the intention of thanking the partner he said, so that the speech is included in the act of illocution speech. The "Thank you" speech goes into a kind of expressive illocution speech. P1 intends to buy chicken meat to his liking to P2. Then P1's desire for the required chicken meat was responded well by P2. P2 
comply with all P1 requests regarding chicken meat required. P2 cuts the chicken neck thoroughly and without including the chicken neck to be weighed with the meat, in accordance with the request of P1 because the chicken meat is needed to make meatballs, so that P1 is satisfied with the service provided by P2. P1's satisfaction with P2 is expressed with the word "Thank you". P1 would like to thank P2 for the service provided by P2. Based on the analysis, it can be concluded that data number (2) belongs to the type of expressive speech.

Based on its social purpose, the speech "Thank you" has another purpose of looking for a chance to be friendly, namely P1 expresses gratitude because P1 is satisfied with the service provided by P2. "Thank you" is an expression of gratitude. Saying thank you is part of the fun function (convivial). Based on the explanation of data number (2) it can be concluded that the speech "Thank you" is a function of pleasant illocution (convivial) speech.

\section{b. Data (10)}

\section{Context:}

Told by the seller of es cendol (P2) with the buyer (P1) who had previously preordered es cendol, and had subscribed with this ice cendol seller.

P1: "Wis gawekna wholesale nyong? Wis gawekna wholesale?" ("Have you made me yet? Have you made it yet?")

P2 "Lha iki" ("This")

P1: "Nyong arep beli, rene" ("I want to go home, here")

P2: "Karo es ora iki, ora?" ("Same ice or no?")

P1: "Karo es ya kono ora ya jedor, sak weine" ("Same ice yes please, not yes let it, as dedicated")

P2: "Maer temen yahene wis buy" ("It's so good at this hour to be home")

P1: "Ora usah karo mberoh-mberoh cendol bae. Telong ngewu?" ("Don't be the same weird cendol. Three thousand")

P2: "Ho.o, klamet, gak beli pa" (receive money) ("Yes, excuse me, what do you want to go home for?")

P1: "Beli" ("Go home")

P2: "Kana ngati ati-ati" ("Go there carefully") 
In the data number (10) in the form of the word "I want to go home, here" is a turuan delivered by P1, namely buyers to P2 sellers of ice cendol. The saying "I want to go home, here" has the intention of governing to the opponent of speech, so that the speech is included in the act of speech illocution. Speech on data number (10) is intended P1 so that P2 can do what he said. The word "I want to go home, here" is included in the kind of follow-up to the directive. Based on existing context, the naration "I want to go home, here" indirectly has the intention of ordering the opponent said P2 so that P2 accelerate the manufacture of ice cendol that has been ordered before, it is because that P1 has felt long enough to wait for the order of ice cendolnya and he hastened to return home immediately, so P2 tried to accelerate the manufacture of ice cendol for P1. Based on the analysis, it can be concluded that data number (10) belongs to the type of speech illocution directive.

The speech in the form of "I want to go home, here" has the goal of illocution along with the social goal of negative manners to reduce disharmony. The speech data number (10) is interpreted P1 ordered the opponent said P2 so that P2 accelerate the manufacture of ice cendol that has been ordered in advance. Governing is part of a competitive function. Based on the analysis, it can be concluded that data number (10) is included in the function of competitive illocution speech.

\section{c. Data (8)}

Context:

Communication between the seller tofu (P2) and the buyer (P1), the buyer wants to buy white tofu that has been cut into pieces. (P1) ask about the price of tofu sold.

P1: "Niki tahune pintenan?"

He said, "How much for this tofu?"

P2: "Four five thousand"

("Four five thousand")

P1: "Empat, Lima ribu!?"

("Four, five thousand!?")

P2: "Nggeh, tahune piyambak, murah" ("Yes, tofu yourself, cheap")

P1: "Berarti empat sementen kotak?" ("Means four squares")

P2: "Berarti empat sementen kotak" 


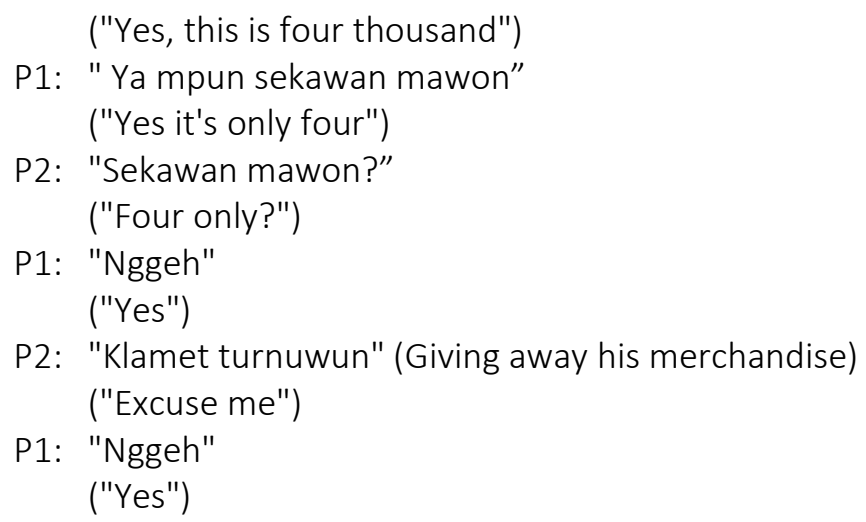

Data number (8) in the form of speech "Yes, tofu yourself, cheap" is a speech delivered by the seller tofu or P2 to buyers P1. The speech "Yes, tofu yourself, cheap" contains the intention that P2 stated something to P1 opponents he said, so that the speech is included in the act of speech illocution. The speech on data number (8) has the intention of giving a statement that binds P2 to the correctness of the existing proposition regarding the know-how it sells. The speech "Yes, tofu yourself, cheap" including speech that states something, so that the speech goes into the type of act of asertif illocution. The speech "Yes, tofu yourself, cheap" directly has the intention of stating that the white tofu that $\mathrm{P} 2$ sells is the result of tofu that it produces itself, so the price becomes cheaper. It is intended P2 to convince P1 that the tofu he sells is already really cheap because of his own production. Based on the analysis, it can be concluded that data number (8) belongs to the type of speech illocution asertif.

The words "Yes, tofu yourself, cheap" are included in the statement sentence. Speech in data number (8) is a speech that does not care about social purposes, namely manners. The speech "Yes, tofu yourself, cheap" including a speech stating that the white tofu that P2 sells is the result of tofu that it produces itself, so the price becomes cheaper. States are part of a function of working together. Based on data analysis number (8) it can be concluded that the speech "Yes, tofu yourself, cheap" is a speech that belongs to the function of collaborative illocution.

\section{d. Data (1)}

Context: 
It occurs when there is a spice trading interaction conducted by seasoning traders and their buyers in Wonosobo Kejajar Market. The buyer will buy the pecan seasoning, in the middle of the transaction of buying and selling pecan seasoning the seller intends to offer his other merchandise. P1 (buyer) and P2 (seller).

P1: "Sek gedhe nana pa mba' iki? ya mb?"

("The big one is not what's going on' is this? Yes mb?")

P2: "Nana, telu opo papat Bu?"

("Nothing, three or four ma'am?")

P1: "Papat piro?"

("Four how?")

P2: "Sepuluh ribu."

"Ten thousand."

P1: "Ya wis papat."

("Yes it's four")

P2: "Apa maning? Uwis? Kie Ndangdut asli Bu"

("What else? Already? This is the real Ndangdut Ma'am")

P1: "lya porah, wis ngerti"

("Yes let it be, already know")

Data number (1) in the form of a speech "What else? Already? This is the real Ndangdut Ma'am" delivered by the seller of P2 seasoning to the buyer of P1. The naration "What else? Already? This is the real Ndangdut Ma'am" contains the intention that the spice merchant offers his merchandise, so that the speech is included in the act of illocution speech. The naration "What else? Already? This is the real Ndangdut Ma'am" can influence opponents he said that is so that opponents he said buy salt offered. The naration "What else? Already? This is the real Ndangdut Ma'am"belongs to the type of illocution komisif illocution. The statement "This is the real Ndangdut Ma'am" spoken by P2 to offer its merchandise namely salt with the original Ndangdut brand to the buyer or partner said, it is expected that the partner said or P1 can buy the merchandise. Based on data analysis number (1) it can be concluded that the speech "What else? Already? This is the real Ndangdut Ma'am" belongs to the type of illocution komisif illocution.

Based on his social goals, the saying "this is the real Ndangdut Ma'am" has another purpose, namely hoping that P1 or buyers can buy salt under the brand Ndangdut that he offers. Said "What else? Already? This is the real Ndangdut Ma'am" containing an offer. The offer is part of a fun function (convivial). Based on the explanation of data number (1), it can be concluded that the speech "What 
else? Already? This is the real Ndangdut Ma'am" delivered by P2 to P1 is offering, so that the act of speech is a function of pleasant illocution (convivial).

2. Relevance of the Results of Illocution Speech Analysis in the Interaction of Promotion with Buyers to Indonesian Language Learning in High School.

Based on research that has been done by researchers, the results of the Illocution Speech Action research in Wonosobo Kejajar Market can be relevanized to indonesian language learning, although not directly. This research can be attributed to The Standard of Competence and Elementary Competency in High School (SMA) grade $X$, namely the linguistic aspect of a text. The text reflected in the results of this study is the negotiating text. Basic Competencies (KD) associated with the results of this study are KD 3.11 Analyzing the content, structure (orientation, submission, offer, approval, closing) and language of the negotiating text. The speeches obtained from the results of this study can be an example of negosisasi text speech because the speeches coming from Wonosobo Kejajar Market is an interaction between two people, namely P2 sellers and P1 buyers in which contains a discussion in order to reach a mutual agreement without coercion. Basic competencies and indicators that can be used as the focus of learning in the learning plan are as follows.

\section{Table.3 KD and Competency Achievement Indicators}

\begin{tabular}{|l|l|}
\hline Basic Competencies & Indicators \\
\hline $\begin{array}{l}\text { 3.11 Analyze the content, } \\
\text { structure (orientation, } \\
\text { submission, offer, approval, and } \\
\text { closing) and the language of the } \\
\text { negotiating text }\end{array}$ & $\begin{array}{r}3.11 .1 \text { Determining parts of the structure } \\
\text { of the negotiating text }\end{array}$ \\
& $\begin{array}{l}3.11 .3 \text { Analyzing the language of } \\
\text { negotiated texts }\end{array}$ \\
\hline
\end{tabular}

\section{E. Conclusion}

From the speech data that has been collected by researchers after the analysis, 41 speech data were produced that belonged to the types and functions of ilokusi actions carried out by sellers with buyers in Wonosobo Kejajar Market. The data found in these types of ilokusi speech acts consisted of 7 data on expressive speech types, 17 data on types of speech directives, 11 data on types of asertive speech actions, 6 data types of 
commissionive speech, while for the type of declarative ilokusi speech action was not found. In addition, the ilokusi speech function found consisted of 17 competitive function data, 13 data of fun functions (convivial), 11 data of collaborative functions, while for speech actions that belonged to conflictive functions were not found.

The speech found from the analysis of this research can be used as an example of text in learning materials in schools. This can make it easier for students to understand the material given because the examples given come from real-life problems that are not uncommon for students. Learning materials that can be relevanized with this research is the Indonesian language learning material negotiated text. Therefore, the relevance of ilokusi speech between sellers and buyers in Wonosobo Kejajar Market to learning is contained in the negotiating text material in sma class X, in KD 3.11 Analyzing the content, structure (orientation, submission, offer, approval, closing) and the language of the negotiating text, namely as an example of the negotiating text in which it can be analyzed in accordance with the parts of the negotiation text.

\section{F. Advice}

Based on the above conclusions, researchers expect this research can be used as a reference for other researchers in developing broader research, on pregmatic studies that have not been unedated in this study such as the type and function of ilokusi and perlokusi speech actions conducted by sellers with buyers in the market. The results of this study are also expected to be a reference for educators in Indonesian language learning, especially making the findings as an example of the text of negotiation text learning materials in schools to make it easier for students to understand the material.

\section{BIBLIOGRAFI}

\section{- Books}

Anggito, Albi, dan Johan Setiawan. 2018. Metodologi Penelitian Kualitatif. Sukabumi: CV Jejak.

Barlian, Eri. 2016. Metodologi Penelitian Kualitatif dan Kuantitatif. Padang: Suka Bina Press.

Ismawati, Esti. 2012. Metode Penelitian Pendidikan Bahasa dan Sastra. Yogyakarta: Ombak.

Kunjana, Rahardi dan M.Hum. 2019. Pragmatik Konteks Intralinguistik dan Konteks Ekstralinguitik. Yogyakarta: Amara Books.

Moloeng, Lexy J. 2015 Metodologi Penelitian Kualitatif. Bandung: Remaja Rosdakarya. 
Putrayasa, Ida Bagus. 2014. Pragmatik. Yogyakarta: Graha IImu.

Sudaryanto. 2015. Metode dan Aneka Teknik Analisis Bahasa. Yogyakarta: Dita Wacana University Press.

Yule, George. 2006. Pragmatik. Yogyakarta: Pustaka Pelajar.

\section{- Traslation Books}

Leech, Geffrey.1993. Prinsip-Prinsip Pragmatik, (translate by M.D.D. Oka). Jakarta: Universitas Indonesia.

\section{- Journals}

Ediwarman, 2019, Analisis Tindak Tutur Ilokusi dalam Novel Tenggelamnya Kapal Van Der Wijck Karya Buya Hamka dan Pemanfaatanya Bagi Pembelajaran Apresiasi Sastra di SMP, Journal Membaca: Bahasa dan Sastra Indonesia, Vol. 4, Issue 1, April 2019. https://jurnal.untirta.ac.id/. Accessed on June 9, 2020 at 12:16 pm.

Giyanti, Rizki Joko Nurcahyo dan Diah Iskafatmawati Saputri. 2019. Tindak Tutur Illocution dalam Lirik Lagu Album Monokrom Karya Muhammad Tulus Rusdy, Academia: Journal of Multidisciplinary Studies, Vol. 3, Issue. 1, Januari-Juni 2019. https://ejournal.iainsurakarta.ac.id/. Accessed on June 30, 2020 at 11:36 am.

Herliana, Monika, 2019, Tindak Tutur Illocution Pengajar Pada Proses Pembelajaran Bahasa Mandarin, Jurnal Ilmiah Lingua Idea, Vol. 10, Issue. 2, Desember 2019. http://jos.unsoed.ac.id/. Accessed on April 9, 2020 at 08.30 am.

Prayitno, Harun Joko, 2009, Perilaku Tindak Tutur Berbahasa Pemimpin dlam Wacana. Rapat Dinas: Kajian Pragmatik dengan Pendekatan Jender, Kajian Linguistik dan Sastra, Vol. 21, Issue. 2, Desember 2009. http://journals.ums.ac.id/. Accessed on November 21, 2020 at 07.22 am.

Riyanton, Muhammad, 2020, Fungsi Peribahasa Banyumas, Jurnal Pembahsi, Vol. 10, Issue. 1, Februari 2020. https://jurnal.univpgri-palembang.ac.id/. Accessed on November 30, 2020 at 04.00 pm.

Siddiq, Mohammad, 2019, Tindak Tutur dan Pemerolehan Pragmatik pada Anak Usia dini, Kredo: Jurnal Ilmiah Bahasa dan Sastra, Vol. 2, Issue. 2, April 2019. https://jurnal.umk.ac.id/. Accessed on June 30, 2020 at 01.29 pm. 